Laboratory he has seen its transfer from the Treasury to the Department of Scientific and Industrial Research. He was created C.B.E. in 1958.

Dr. D. T. Lewis

DR. D. T. LEwis, who has been appointed Government Chemist, was born in Breconshire in 1909 and graduated at the University College of Aberystwyth with first-class honours in chemistry in 1930. $\mathrm{He}$ afterwards gained the degrees of Ph.D., and D.Sc., of the University of Wales. Prior to the War, he occupied various teaching posts and held lectureships at the University Colleges of Aberystwyth and Cardiff. In 1941, Dr. Lewis joined the Armaments Research Establishment of the Ministry of Supply and was associated with research and development work on conventional armaments. Leaving this work he was appointed one of the early members of Sir William Penney's atomic weapons team, and for the past seven years he has held the post of senior superintendent of the Chemistry Division at the Atomic Weapons Research Establishment, Aldermaston. In addition to his duties at Aldermaston he has also taken part in overseas trials in Australia and at Christmas Island. $\mathrm{He}$ has published a large number of papers in the various scientific journals dealing with inorganie physical and analytical chemistry. $\mathrm{He}$ has also published "Ultimate Particles of Matter", a book designed as an introduction for laymen to nuclear and associated sciences. Dr. Lewis is chairman of the Thames Valley Section of the Royal Institute of Chemistry and has been a representative of the Atomic Energy Authority on the board of governors of the Newbury Technical College.

Lucas Heights Research Establishment, Australia : Dr. G. C. J. Dalton

Dr. George Clifford James Dalton has been appointed director of the Lucas Heights Research Establishment of the Australian Atomic Energy Commission. Dr. Dalton was born at Te Awamutu, New Zealand, in 1916 and was a Rhodes Scholar in 1936. From Oxford he went to the Royal Air Force where he was occupied with radar research. At the end of the Second World War he went to Harwell, where he was in charge of the Fast Reactor Group of the United Kingdom Atomic Energy Authority. This Group carried out the early scientific work which led to the decision to construct the fast breeder reactor at Dounreay. During 1949-55, he was professor of mechanical engineering at Auckland University, New Zealand. Dr. Dalton joined the staff of the Australian Atomic Energy Commission in 1955 as chief engineer and deputy chief scientist.

\section{Second Nuclear Reactor for Lucas Heights}

A SECOND nuclear reactor is being installed at Lucas Heights by the Australian Atomic Energy Commission. In announcing this, the Minister for National Development, Senator Spooner, explained that it will be a small and simple apparatus by comparison with the Commission's first reactor, Hifar (see Nature, 181, 1433; 1958). It will be used in the Commission's general programme for the development of a high-temperature gas-cooled reactor and will be complementary to Hifar, which was a $10,000-\mathrm{kW}$. materials testing reactor used also for making radioisotopes. Production of isotopes, which has already begun, forms an important part of the Lucas Heights programme. The new reactor will produce $10 \mathrm{~kW}$. and will be employed for many tests and measurements where the intense radiation of Hifar is unnecessary. These will include physics studies of reactor material, and sample cores (fuel assemblies) for future power-reactor systems. Because of its simplicity and inherent safety of operation, the new reactor will also be used for training staff who will eventually work on other reactors. It is expected that the cost of installing the new reactor and its

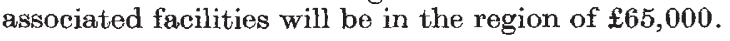

\section{The Game Research Association}

A National organization to be known as the Game Research Association has been formed, by a responsible group of farmers, landowners and others interested in game conservation, to promote game research in Britain. The Association will be financed entirely by donations and membership subscriptions, and will carry out research into all factors controlling the game population of the country. The subjects to be studied, as funds and staff become available, include ecology of partridges and pheasants in relation to agriculture, forestry and other land use, regarding game as a natural resource; and also the more immediate problems of game mortality such as gapeworm, the effects of toxic chemicals and effective re-stocking methods. Laboratories for a temporary research headquarters are being loaned by Imperial Chemical Industries, Ltd,, at Fordingbridge. The president of the Association is Mr. Harold Macmillan, and vice-presidents, Sir John Ruggles-Brise and Major John Morrison; chairman of council, Lord Porchester. Mr. A. D. Middleton, director of the Imperial Chemical Industries Game Research Station, Fording. bridge, is honorary research adviser, and Mr. F. O. G. Lloyd is honorary secretary-treasurer (temporary London office at 7-8 Great Winchester Street, London, E.C.2).

\section{The I.C.I. Game Research Station, Fordingbridge}

THE work of this Station at Fordingbridge, in Hampshire, will continue, but with some reduction in the research projects and more emphasis on advisory and educational work. Research will include methods of artificial propagation and population dynamics. The advisory staff will continue, through personal visits, literature and other means, to give practical application to the knowledge which has been gained during fourteen years of work at Fordingbridge and, in pre-war years, in Hertfordshire and other places. Naturally, Imperial Chemical Industries, Ltd., welcomes the formation of an independent Game Research Association, which should be able to expand research in this field. The Fordingbridge team will collaborate in every possible way in the work of the Association.

\section{Research on Grouse}

In addition to the Game Research Association, and the work of the Imperial Chemical Industries Game Research Station, a third research project, concerning grouse, is now firmly established. The ecological study of grouse in Scotland, under the direction of Prof. V. C. Wynne-Edwards, of the University of Aberdeen, financed for the past three years by the Scottish Landowners Federation, is now being taken over and expanded by the Nature Conservancy. This is to be part of a wider project, known as the Unit of Grouse and Moorland Ecology, the first of such units to be operated by the Conservaney. Its research results, from a long-term study of grouse population dynamics, will inevitably be of 